\title{
A COMPREHENSIVE ACCOUNT ON THE INSECT DIVERSITY POTRAYED IN THE HOLY QUR'AN
}

\author{
Muzafar Riyaz \\ Division of Taxonomy and Biodiversity, Entomology Research Institute, Loyola College \\ Nelson Manickam Rd Chennai, Tamil Nadu, India. 600034 \\ Email: bhatmuzaffar471@gmail.com
}

\begin{abstract}
Insects are one of the most fascinating groups of organisms that evolved some 300 million years back in the Devonian period. With the remarkable body structure, shape, and flight adaptability, Insects have outnumbered every other organism and become the dominant group of organism's earth has ever witnessed. Insects deliver a number of ecosystem services like pollination of flowering crops, as decomposers, vectors, pests, predators, etc. Since insects play an important role in human life; a number of Insects have been mentioned several times in the holy Quran. The present study is a review of the insects that have been described in the Quran. In the present era of large-scale industrialization, urbanization and many other factors like climate change, global warming, pesticide pollution; insect diversity is under a very serious threat and many species are on the verge of extinction and a number of species are threatened and vulnerable including some species of bees. Management and conservation of these precious species are need of the hour and cutting-edge strategies can save these insects from further decline.
\end{abstract}

Keywords: famines, holy Qur'an, honeybees, insects, locusts

Abstrak: Serangga adalah salah satu kelompok organisme yang paling menarik yang berevolusi sekitar 300 juta tahun yang lalu pada periode Devon. Dengan struktur tubuh, bentuk, dan kemampuan beradaptasi yang luar biasa, serangga telah melebihi jumlah organisme lain dan menjadi kelompok organisme dominan yang pernah disaksikan bumi. Serangga memberikan sejumlah jasa ekosistem seperti penyerbukan tanaman berbunga, sebagai pengurai, vektor, hama, predator, dan lain-lain. Karena serangga memainkan peran penting dalam kehidupan manusia; sejumlah serangga telah disebutkan beberapa kali dalam Al-Qur'an. Kajian kali ini adalah ulasan tentang serangga yang telah dijelaskan dalam Al-Qur'an. Di era industrialisasi skala besar saat ini, urbanisasi dan banyak faktor lain seperti perubahan iklim, pemanasan global, dan polusi pestisida, keanekaragaman serangga berada di bawah ancaman yang sangat serius dan banyak spesies berada di ambang kepunahan dan sejumlah spesies terancam dan rentan termasuk beberapa spesies lebah. Pengelolaan dan konservasi spesies berharga ini diperlukan saat ini dan strategi mutakhir dapat menyelamatkan serangga ini dari penurunan lebih lanjut.

Kata Kunci: Al-Qur'an, belalang, kelaparan, lebah madu, serangga

\section{Introduction}

Insects (Insecta: Arthropoda: Animalia) belong to the phylum Arthropoda and accomplish a special class of organisms in the Animal Kingdom and are widely recognized as the most successful organisms ever to take possession of the planet earth. The species are dominant in almost all of the habitats as they are residing in every nook and corner of the earth. The insects were evolved in the Devonian period with fossil records dating back 300 million years ago (Engel, 2015). Insects are everywhere and outnumber every other living organism on the planet. Insects can be found in households, lawns, agricultural fields, forests, cities, towns, inside the tree barks, under the soil, inside the dead animal and plant matter, deserts, and so on. The distinguished roles played by Insects in all biological systems makes them one of the prevailing class, the earth at any point saw. The potential to withstand any climatic condition, lightweight, small size, flight capability makes them significantly versatile to endure and reproduce faster than some other living forms on the planet. Insects were the first animals to ever develop the ability to fly. Since evolution usually works with what it has; new body structures do not crop up very often. However, in the case of insects, they did not use modified limbs to fly. The insect wings are a brand-new innovation in their physiology. The development of wings among them is so unusual that scientists are still working on, and arguing about how and when insect wings first came about (Tauber \& Tauber, 1981). Nearly 
more than 1 million insect species have been discovered so far and scientists estimate that there could be millions more waiting to be discovered. The faster reproductive rate, flight ability, lightweight, unique body structures, and major roles in different ecosystems make them the most dominant animals the earth has ever witnessed.

\section{Insects and Their Importance}

Insects play major roles in our environment, however; insects are some of the most misunderstood and underappreciated animals on earth due to their capacity to destroy crops and carry diseases. Yet, insects are very crucial for the better functioning of many ecosystems. One of the most important services that insects deliver is pollination. Insects help in the pollination of around $80 \%$ of the angiosperms across the globe (Riyaz et al., 2018). Insects are very important in the systematic functioning of many food chains and food webs as they provide food for many animals including birds, amphibians, and reptiles. There are many significant assets that insects have been provided to Humans like Honey, Silk, Lac, Wax, etc. Besides feeding on our crops and vegetables as pests, numerous insect species play crucial roles in eliminating many pest species as predators and parasitoids (Figure 1). Many predatory and parasitoid species of insects feed on Mosquitoes, aphids, pest caterpillars, and mealybugs that destroy fruits and vegetable crops, therefore acting as biological control agents in our ecosystems. Insects have been used in molecular and genetic studies, forensic sciences, and many other biological studies including therapies. Many insects such as dragonflies act as biological indicators in the environment. These species help in monitoring the biological quality of water as there are very sensitive to pollution. Most of the insect species help in environmental remediation as they spend most of their lives underwater or inside soils. Insects play a very crucial role in the decomposition of plant and animal matter. The role of insects is so crucial that if insects and other land-dwelling arthropods were to become extinct, then it would sound like the death knell for all the earthlings. The majority of the birds, reptiles, and mammals, and amphibians would soon fizzle out to extinction. Next in line be the flowering plants, the physical structure of the forests and soon other terrestrial habitats will suffer equatorial damage due to the disturbance in the food chains and food webs. Apart from ecosystem services, insects have been mentioned in the folklores of many tribes and communities of peoples from all over the world. Many traditions across the globe have considered insects as the treasures of the world. The ecosystem services delivered by insects on the planet are innumerable. However, due to some anthropogenic activities, the populations of many insect species are rapidly moving towards engendering and extinction (Jankielsohn, 2018).

\section{Insects Described in The Holy Quran}

Holy Quran; one of the sacred books of Islam was revealed upon Prophet Muhammed (PBUH) orally through archangel Gabriel (Jibril) by Allah during a time period of 23 years between 610-632 A.D. Followed by the death of the Prophet, the Quran was later assembled in the form of Surahs (chapters) by the companions of Prophet that served as scribes and recorded or memorized the revelations. Analyzing the text of the Quran; a direct message has been given to all mankind in every aspect of life (Naik, 1999; Mohammad, 2020). A number of verses in the Quran have been analyzed that are reflecting modern-day scientific research and a lot is yet to be ascertained by scientists and Islamic researchers.

Insects as mentioned earlier are one of the most fascinating and dominant creatures, planet earth has ever witnessed. From pollinating $80 \%$ of the global crops to killing millions of humans annually across the globe, the insects have achieved a higher rank and dominant place in the animal kingdom in every aspect of their contribution to most of the ecosystems. A few studies have enlisted some insects that have been described in the Quran (El-Mallakh \& El-Mallakh, 1994; Khalid, 1999; Tlili, 2012; Naveed et al., 2016). However, the present study will provide a detailed and comprehensive note on all of the insects and their roles that are mentioned in the Holy Quran. 


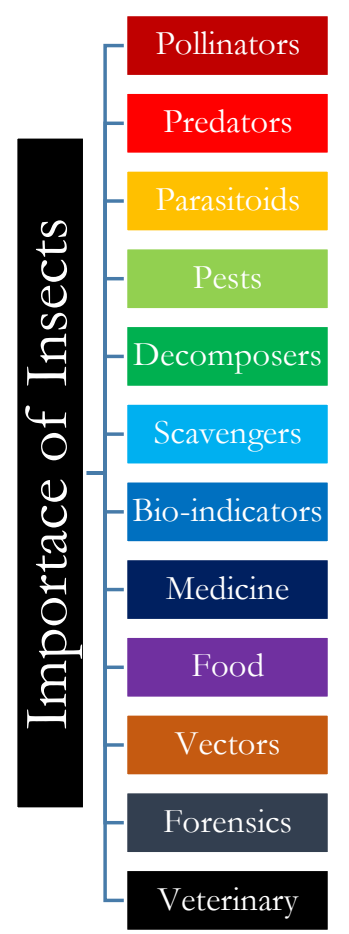

A. Honey Bees

Figure 1. Importance of Insects

Systematic Classification

Phylum : Arthropoda

Class : Insecta

Order : : Hymenoptera

Genus : Apis

Meaning:

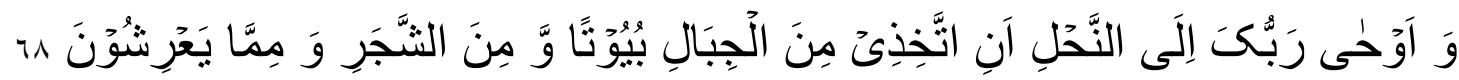

And your Lord inspired the bee, saying: "Take you babitations in the mountains and in the trees and in what they (bumans) erect." (QS. Nahl: 68).

Honey bees belong to the family Apidae of order Hymenoptera and are regarded as one of the most important animal species in the animal kingdom. Honey bees act as the most efficient and numerous pollinators of most of the flowering plants and crops in both natural and agricultural ecosystems thus supporting the growth and development of the world flora (Figure 2). Honey which is a sweet viscous food substance is produced by the bees from the family Apidae is a composition of glucose sugars and fructose. Honey is produced by the bees as a result of sugary secretions from the flowering plants by the process of regurgitation, enzymatic activity, and water evaporation. It takes a bee to fly around 90000 miles which is equal to three times flying around the globe to make one pound of honey. Honey is a precious gift from nature and has been used by humans since time immemorial as food and as a medicine to treat a number of diseases. Honey has antioxidant, antibacterial, antifungal, antidiabetic properties and many studies have shown that it has anticancer as well as immune-boosting properties (Purbafrani et al., 2014; Channa et al., 2018)). Apart from pollination and honey, bees also produce wax which has an end number of properties as well. Bee wax can be used in skincare, microbial infections, candle making, antiallergic, wound healing, cracked lips, wood polish, etc. Beekeeping or Apiculture is the maintenance of bee colonies in man-made beehives. It has been introduced for the scientific rearing of honey bees for the commercial production of honey, wax, pollen, royal jelly, and bee venom. Apiculture has provided a lot of self-employment among common people thus directly responsible for generating economy as well. 


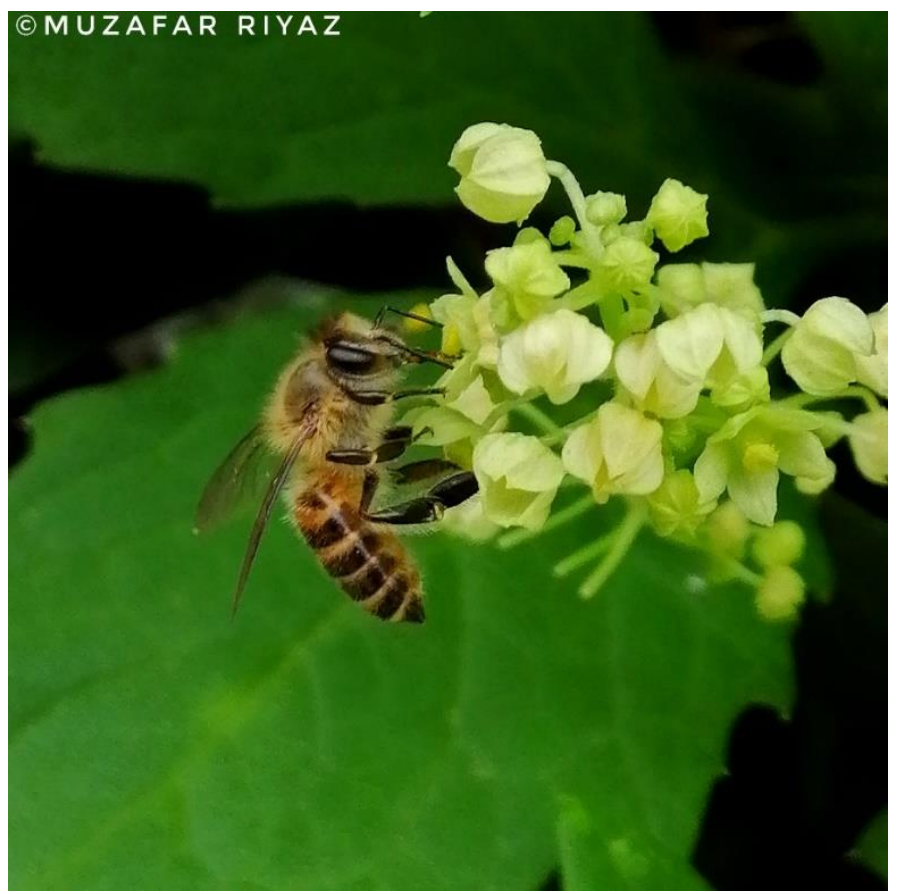

Figure 2. A Honey bee

Nahl, the 16th chapter in the Holy Quran has acquired its name from a bee [Nahl (Arabic)=Bee]. A little description of the honey bee has been mentioned in the 68th verse of this chapter. The comparison in the adaptability between the bees (specifically the honey bee) and the humans is well versed by the instructions of Allah to the bees.

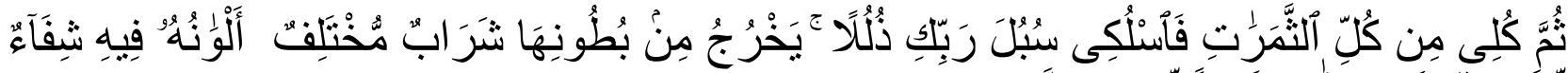

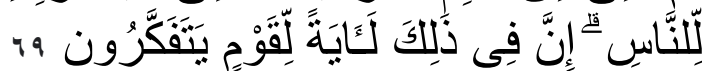

Meaning:

"Then, eat of all fruits, and follow the routes that your Lord made easy (for you)." There comes forth from their bellies, a drink of varying colors, in which there is a cure for men. There is indeed a sign in that for people who reflect (QS. Nahl: 68).

In the 69th verse of the chapter An-Nahl, Allah has provided more instructions to the bee as to suck the nectar from fruits and flowers. Bees usually get their energy from the nectar of flowers and at the same time, they transfer the pollen from one flower to another. Thereby pollinating $80 \%$ of the flowering plants across the world as well. In the next sentence of verse 69, Allah has given the indication of honey to mankind and with the advancement of scientific research, it has been analyzed that honey is the cure for hundreds of health ailments. Prophet Mohammad (PBUH) has also conversed about honey and its uses to his companions.

B. Ants

Systematic Classification

Phylum : Arthropoda

Class : Insecta

Order : Hymenoptera

Ants belong to the family Formicate of the order Hymenoptera. Ants are considered as one of the social-rich of all social insects. The division of labour and polymorphism within the ant colonies have changed the scientific and public interest (Figure 3). Ants are considered as one of the strongest creatures ever existed on this planet in relation to their size. An ant can carry 50 times of its body weight as these little creatures can be seen carrying twigs, leaves to their nests. Ants are unique insects and the matchlessness of these insects is exhibited while they work in and around their nests (Ward, 2014). 


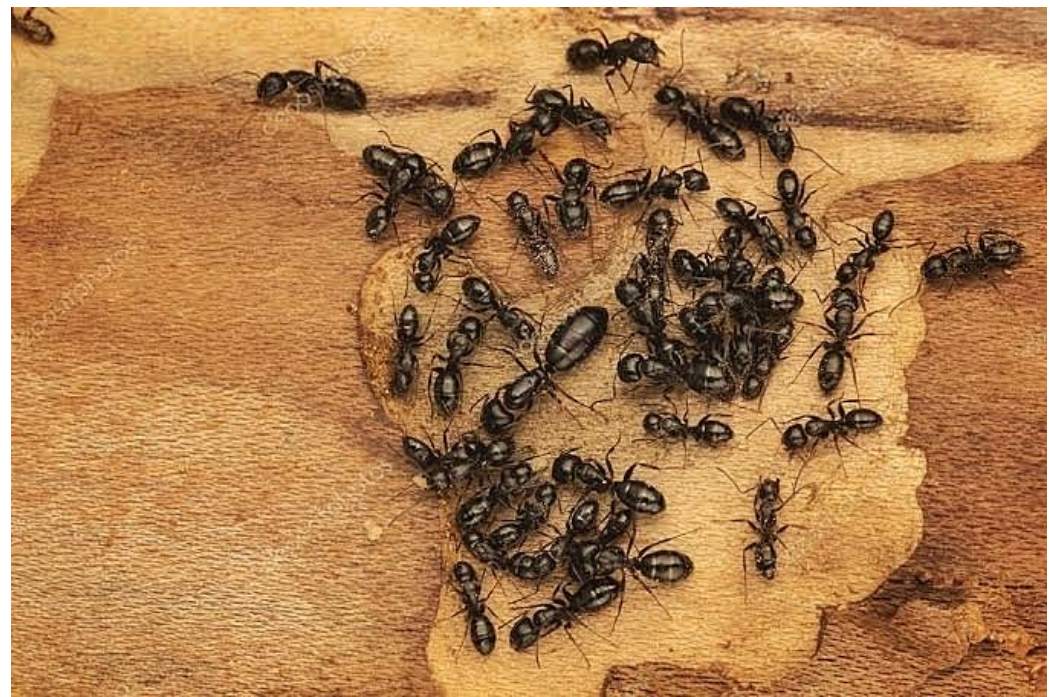

Figure 3. A Black ant colony

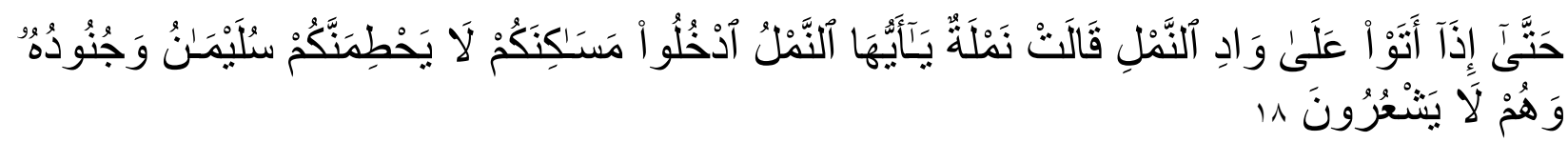

Meaning:

Till, when they came to the valley of the ants, one of the ants said: "O ants! Enter your dwellings, lest Sulayman and his armies should crush you, while they perceive not" (QS: Naml: 18).

$\mathrm{Naml}$, the 27th chapter in the Holy Quran has acquired its name from an Ant [Naml (Arabic)=Ant]. Although this chapter has attained its name from the Ants. However, the chapter has discussed the life of Prophet Sulaiman (AS), since there was a close connection to ants whose conversations were understood by Prophet Sulaiman (AS). Ants hold a special privilege among animals in Islam on account of their relationship with the Prophet Sulaiman (AS). The literature of Hadith has also cited Prophet Mouhammad's (PBUH) forbidding Muslims to kill ants, bees, hoopoe, and shrike.

C. Butterflies/Moths

Systematic Classification

Phylum : Arthropoda

Class : Insecta

Order : Lepidoptera

Division $^{1} \quad$ : Rhopalocera (Butterflies)

Division $^{2} \quad$ : Heterocera (Moths)

Butterflies and moths (Lepidoptera: Insecta) are one of the fascinating groups of insects that ever existed in the history of animal evolution. These insects are often recognized by the colorful wings flying during the day hours (butterflies) and night hours (moths) as well. The order Lepidoptera is having both agricultural as well economic importance as the species from the order Lepidoptera are pests to many crops across the globe. Several other species have attained a special class of economic importance class by producing the silk and most of the species are pollinators to many flowering plants as well. The order Lepidoptera is distributed across 126 families and more than 18000 species of butterflies (Figure 4), moths (Figure 5), and skippers have been described across the globe (Vane-Wright \& Ackery, 1984; Riyaz et al., 2021). 


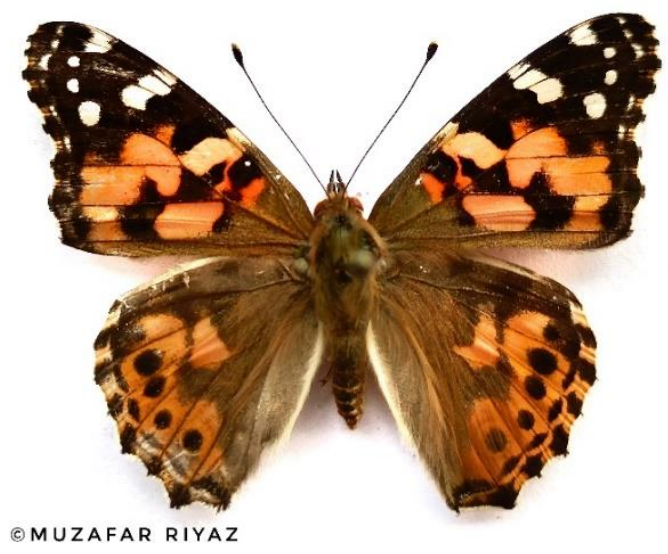

Figure 4. A painted lady butterfly

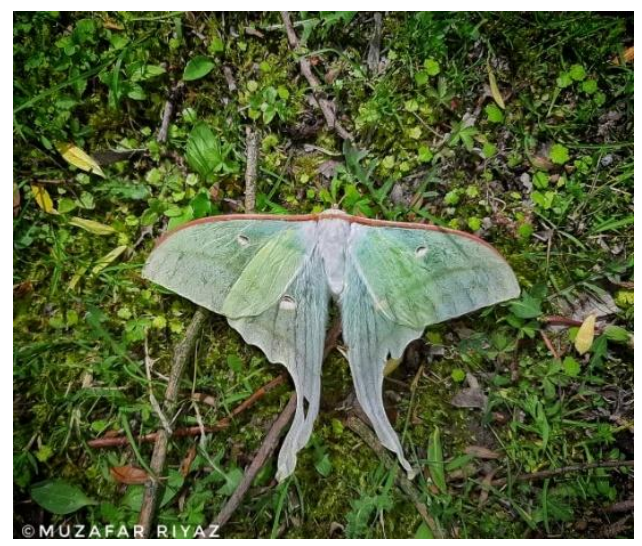

Figure 5. A moon moth

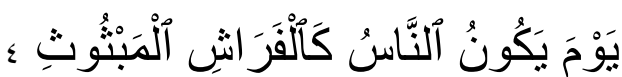

Meaning:

It is a Day whereon mankind will be like moths scattered about (QS. Qaria: 4)

Qaria, the 101st chapter of the Holy Quran has described end times or the day of the judgment. The chapter has been named after the calamities (Qaria [Arabic]=Calamity) which will be propelled to mankind and all life on the earth during the end times. On the day of the judgment or resurrection, humans will be scattered like butterflies and moths. Since populations of the butterflies and moths develop at a faster rate and the individual species disperse all over the places after their development. Humans will also be dispersed like butterflies and moths during the judgment day as per the Quranic version.

\section{Flies}

Systematic Classification

Phylum : : Arthropoda

Class : Insecta

Order : : Diptera

Flies are the two-winged insects of the order Diptera (Figure 6). Flies are distributed across 150 families with over 150000 species described across the globe. Flies are one of the unique insects with their light bodyweight, flying capability with the two wings supported by the halters which are clubshaped structures that aid during the flight. The remarkable aerodynamics of flight capabilities and adaptations has fascinated researchers and scientists all over the world (Courtney \& Cranston, 2015).

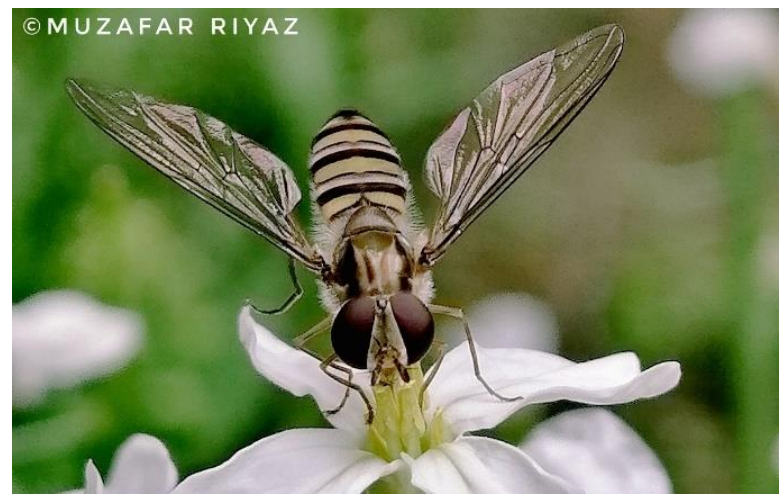

Figure 6. A Marmalade hoverfly 


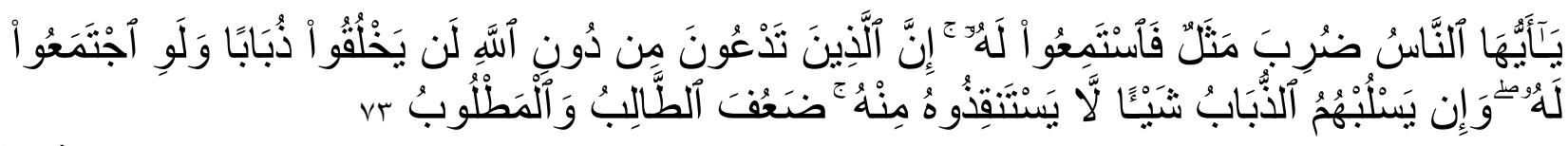

Meaning:

"O mankind! A parable has been made, so listen to it: Verily, those on whom you call besides Allah, cannot create a fly, even though they combine together for the purpose. And if the fly snatches away a thing from them, they will have no power to release it from the fly. So weak are the seeker and the sought."

(QS. Hajj: 73)

Hajj is the 22nd chapter of the holy Quran. In verse 73 of this chapter, Allah has described the brief biology of a fly. If we observe a fly through a macro lens, we can clearly see the unparalleled morphology of this particular insect species. With the advancement of technology, Science has progressed a lot during the past few decades. In the 73 verse of the chapter Hajj, Allah has challenged the whole of mankind, if they all assemble together and can be able to make or create a fly.

E. Mosquitoes

Systematic Classification

Phylum : : Arthropoda

Class : Insecta

Order : : Diptera

Family : Culicidae

Mosquitoes belong to the family Culicidae of order Diptera with over 3600 species reported from all over the world. Mosquitoes are recognized by the slender segmented body, a pair of wings and halters, 3 pairs of hairy-like legs, and elongated mouthparts for sucking the blood (Figure 7). Even though mosquitoes are tiny, however, these insect species are responsible for over 1 million deaths due to the diseases they carry and transmit to humans (Fang, 2010; Foster, 2019).

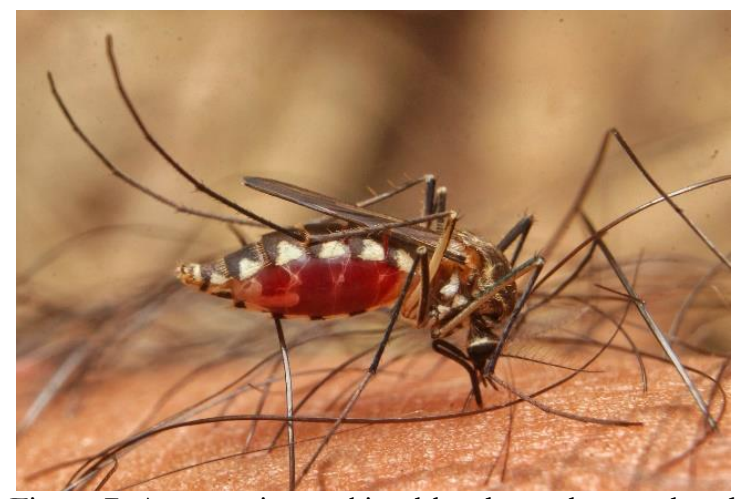

Figure 7. A mosquito sucking blood on a human hand

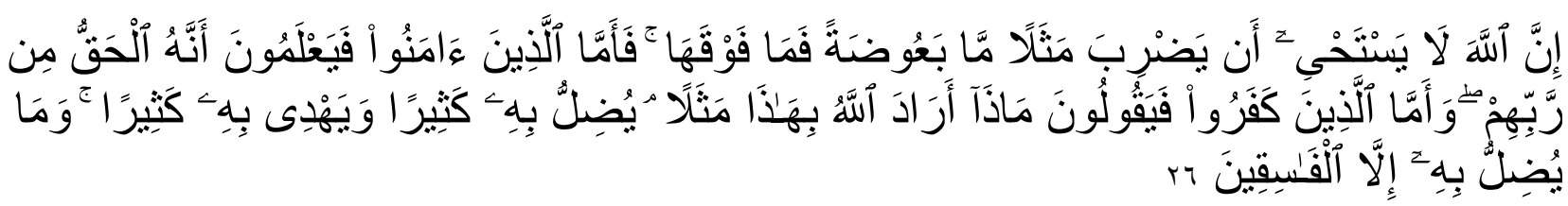

\section{Meaning:}

Verily, Allah is not ashamed to set forth a parable even of a mosquito or so much more when it is bigger (or less when it is smaller) than it. And as for those who believe, they know that it is the truth from their Lord, but as for those who disbelieve, they say: "What did Allah intend by this parable" By it He misleads many, and many He guides thereby. And He misleads thereby only the Fasiqin (the rebellious, disobedient to Allah.

(QS: Baqarah: 26).

Baqarah, the 2nd and longest chapter of the holy Quran. The motto of this chapter is that every human should submit his complete will to the Almighty Allah. In verse 26 of this chapter, everything has 
been made balanced by Allah, be it the parable of a mosquito which is a tiny creature but can damage a lot. Therefore, as per verse 26 of this chapter, it is up to Allah to guide and mislead and Allah only misleads the corrupt and open sinners.

F. Lice

Systematic Classification

Phylum : Arthropoda

Class : Insecta

Order : Psocodea

Family : Pediculidae

Genus : Pediculus

Species : : bumanus capitis (The human head louse)

G. Locusts

Systematic Classification

Phylum : Arthropoda

Class : Insecta

Order : Orthoptera

The human head louse belongs to the family Pediculidae of order Psocodea. The human head louse (Pediculus humanus capitis) is an active obligate ectoparasite of humans. The head louse (Figure 8) is a wingless insect that spends its entire life on the human scalp and feeds on the human blood extensively if not removed or killed. The Head louse is very small in size (2.5-3 mm long) and morphological characters can be visible under a microscope. With the advancement of healthcare medicine, the populations of the head louse have reduced however, the majority of the infestations still occur in rural and tribal populations with a lack of proper medical and wellbeing conveniences (Roberts, 2002).

Locusts are the short-horned grasshoppers that belong to the family Acrididae of order Orthoptera. These particular insect species undergo a swarming phase known as locust phase polyphenism. Locusts are usually solitary however, these species can become gregarious under certain circumstances and therefore become more abundant by changing their behaviour and habits. Locust swarms have devastated the human-grown habitats ever since the ancient Egyptian times of Pharaohs (Firaoun) (Aufi, 2021). Locusts are the oldest-migratory pests and desert locusts are the deadliest among the other species (Figure 9). These pest species can damage a single field of a fully grown crop which can even bring a plague to a particular region or a large proportion of landmass and are therefore considered as the severe pests among other classes of insect pests (White, 1976; Simpson \& Sword, 2008).

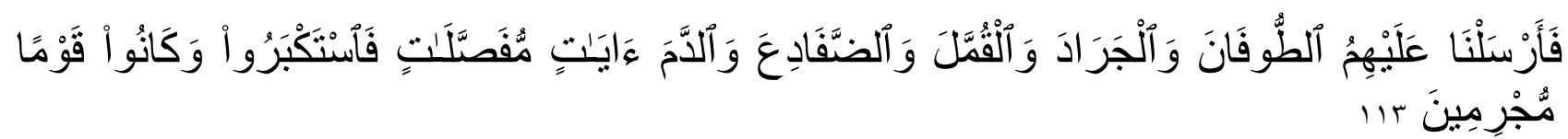

\section{Meaning:}

"So We sent on them: The Tunfan, the locusts, the Qummal, the frogs, and the blood (as a succession of) manifest signs, yet they remained arrogant, and they were of those people who were criminals."

(QS: A'raf: 133).

A'raf, the 7th chapter of the Holy Quran is often referred to as "The Heights". In the 133 verse of this chapter, there is a depiction of certain disasters that are sent on misbelievers like the Floods, locust swarms that destroys the crops and bring plagues, frogs, and the lice that sucks the blood of humans and spread diseases among them. With these calamities being sent upon the misbelievers, however, they remained arrogant and did not repent to Allah. This verse is a clear indication that one should never make a sin or turn away from Allah. Surely, Allah is merciful and powerful. 


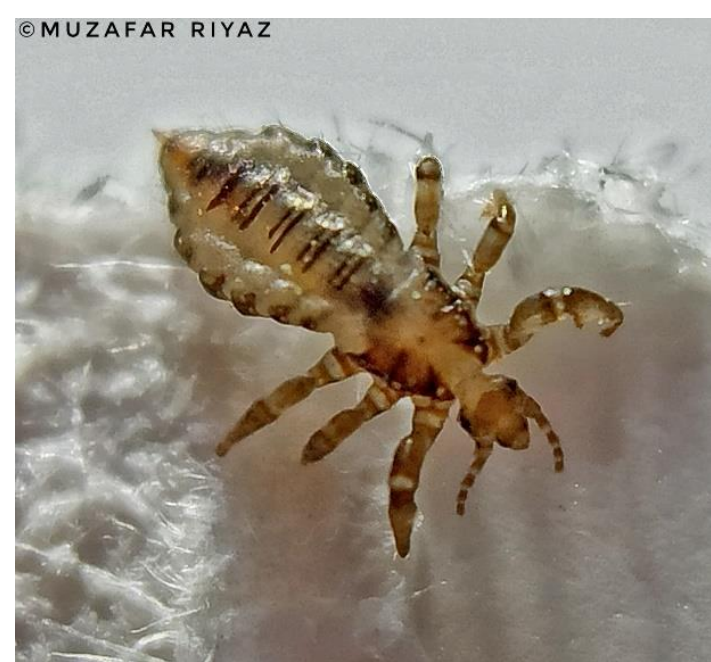

Figure 8. A human head louse

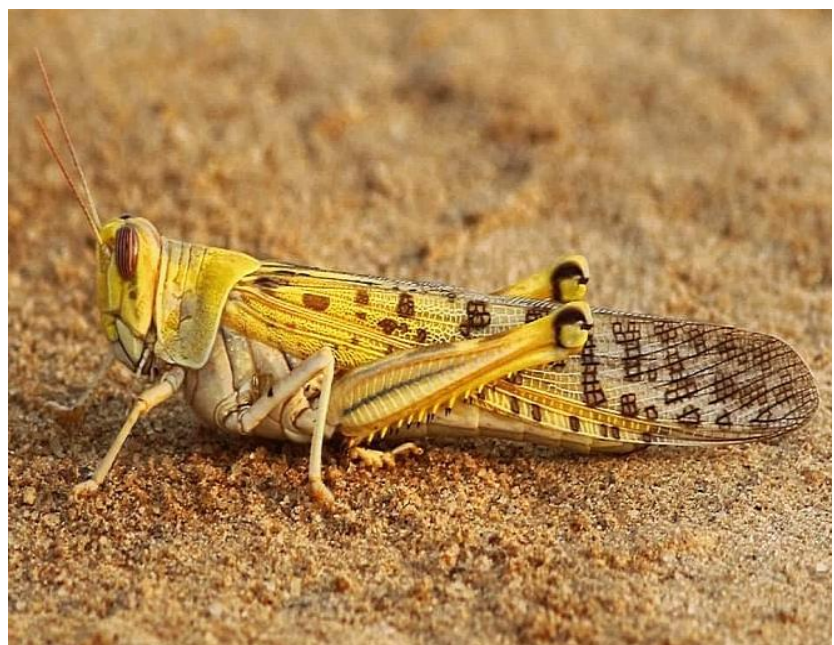

Figure 9. A desert locust

\section{Conclusion}

The insects described in the holy Quran marks the vast diversity of insects. From pollinating the crops to bring plagues, diseases and deaths; Insects have dominated each and every species by their unique body shapes, sizes, flight adaptations, ecosystem services, economical and medical aspects. Insects are certainly one of the most diverse group of organism that ever existed on the planet earth. Their remarkable services in our ecosystems have benefitted humankind from the time immemorial. Although most of the insects are pests to several crops and many other species carry diseases and spread them in humans. But majority of the insects are pollinators, decomposers, bio-indicators, predators, parasitoids which are having enormous benefits and functions within the particular ecosystems.

The insect decline is real. Major proportion of the beneficial insects are under threat by the growing industrialization, urbanization, pesticide use, climate change and global warming (Sánchez-Bayo \& Wyckhuys, 2019; 2021). Steps should be taken to address all the issues that are posing threat to our biodiversity, as the humans cannot live alone.

\section{Acknowledgements}

The author wishes to thank Entomology Research Institute, Loyola College, Chennai, Tamil Nadu, India for extended support and guidance.

\section{References}

Aufi, A. U. 2021. The story of moses and pharaoh in a structural anthropology approach. Jurnal Ushuluddin 29(1): 45-59.

Channa, F. A., Khan, M. A., \& Narejo, N. T. 2018. The benefits of honey and science: Quraa'n and Hadith perspective. Grassroots 52(1): 236-245.

Courtney, G. W., \& Cranston, P. S. 2015. Order Diptera. In Thorp and Covich's Freshwater Invertebrates. Cambridge, Massachusetts: Academic Press.

El-Mallakh, O. S., \& El-Mallakh, R. S. 1994. Insects of the Qur'an. American Entomologist 40(2): 82-84.

Engel, M. S. 2015. Insect evolution. Current Biology 25(19): R868-R872.

Fang, J. 2010. Ecology: A World without mosquitoes. Nature News 466(7305): 432-434.

Foster, W. A., \& Walker, E. D. 2019. Mosquitoes (Culicidae). In Medical and Veterinary Entomology. Cambridge, Massachusetts: Academic Press.

Jankielsohn, A. 2018. The importance of insects in agricultural ecosystems. Advances in Entomology 6(2): 62-73.

Khalid, F. 1999. Qur'an, Creation and Conservation. Birmingham, UK: Islamic Foundation for Ecology and Environmental Sciences.

Mohammad, A. 2020. Qur'an on embryology: A Study of qur'anic and modern concept of human development. Journal of Islam and Science 7(1): 31-38.

Naik, Zakir. 1999. The Quran and Modern Sience Compatible or Incompatible. Islamic Research foundation.

Naveed, H. S., Khan, U. A., Tariq, R. M., \& Dilshad, K. 2016. The honey bees are the beneficial insects for humans, proved by Qur'an, Hadeeth and science. Pakistan Journal of Entomology Karachi, 31(2), 227-234.

Purbafrani, A., Ghazizade Hashemi, S. A., Bayyenat, S., Moghaddam, H. T., \& Saeidi, M. 2014. The benefits of honey in Holy Quran. International Journal of Pediatrics, 2(3), 67-73. 
Riyaz, M., Mathew, P., Paulraja, G., \& Ignacimuthu, S. 2018. Entomophily of Apple ecosystem in Kashmir valley, India: A review. International Journal of Scientific Research in Biological Sciences Vol, 5, 5.

Riyaz, M., Sivasankaran, K., \& Packiam, S. M. 2021. Midnight heroes brought to Daylight: Insights from the National Moth Week-2021 (India). Insect Environment, 24(3), 442-446.

Roberts, R. J. 2002. Head lice. New England Journal of Medicine, 346(21), 1645-1650.

Sánchez-Bayo, F., \& Wyckhuys, K. A. 2019. Worldwide decline of the entomofauna: A review of its drivers. Biological conservation, 232, 8-27.

Sánchez-Bayo, F., \& Wyckhuys, K. A. 2021. Further evidence for a global decline of the entomofauna. Austral Entomology, 60(1), 9-26.

Simpson, S. J., \& Sword, G. A. (2008). Locusts. Current biology, 18(9), R364-R366.

Tauber, C. A., \& Tauber, M. J. 1981. Insect seasonal cycles: genetics and evolution. Annual Review of Ecology and Systematics, 12(1), 281-308.

Tlili, S. 2012. Animals in the Qur'an. Cambridge University Press.

Vane-Wright, R. I., \& Ackery, P. R. (Eds.). 1984. The biology of butterflies. London: Royal Entomological Society.

Ward, P. S. 2014. The phylogeny and evolution of ants. Annual Review of Ecology, Evolution, and Systematics, 45, 23-43.

White, T. C. R. 1976. Weather, food and plagues of locusts. Oecologia, 22(2), 119-134. 